УДК 351:614

DOI: https://doi.org/10.32689/2618-0065-2018-1/1-126-135

Сіцінський Анатолій Станіславович, доктор наук 3 державного управління, професор, завідувач науково-дослідної частини Хмельницького університету управління та права, м. Хмельницький, вул. Героїв Майдану, 8, 29000, Україна, тел.: (038)-27-18-000, e-mail.: info@univer.km.ua

ORCID: 0000-0002-3299-5677

Слюсар Анатолій Андрійович заступник начальника центру заходів цивільного захисту, начальник відділу розвитку цивільного захисту Українського науково-дослідного інституту цивільним захистом,

м. Київ, вул. Рибальська, 8, 01011, Україна тел.: (044)-280-18-01, e-mail.: slusar_vrcz@undicz.dsns.gov.ua

ORCID: 0000-0002-3492-2092

\title{
ОСОБЛИВОСТІ ДЕРЖАВНОГО УПРАВЛІННЯ ТЕХНОГЕННОЮ БЕЗПЕКОЮ
}

Анотація. В статті визначено, що сучасний стан техногенної безпеки України викликає занепокоєння та потребує постійної уваги з боку держави щодо зменшення та попередження ризиків виникнення надзвичайних ситуацій. Аналіз тенденцій збільшення соціально-економічних збитків від надзвичайних ситуацій природного i техногенного спрямування засвідчує необхідність формування ефективної системи управління природно-техногенною безпекою. Автором було акцентовано увагу на тому, що формування системи управління природнотехногенною безпекою повинно базуватись на двох положення, а саме: правильному встановленню кінцевої мети та пошуку відповідних коштів, які забезпечують відповідний рівень такої безпеки. Дослідження обраної проблематики свідчить про необхідність ефективного управління в умовах надзвичайних ситуацій та покращення ефективності координації діяльності офіційних урядових, відомчих і неурядових шляхом розбудови функціональної структури та підвищення кваліфікації управлінських кадрів, але і переходу до нової «управлінської парадигми».

Відзначено, що управління природно-техногенною безпекою це частина системного підходу до прийняття рішень, процедур i практичних заходів у вирішенні завдань з попередження або зменшення небезпеки появи промислових аварій і катастрофічних природних процесів для життя людини, захворювань чи травм, завдання шкоди матеріальним цінностям та навколишньому природному середовищу, зменшення негативних наслідків катастрофічних природних 
процесів. Разом із тим, існуючі тенденції в розвитку природно-техногенних процесів в Україні обумовлюють необхідність подальшої розробки та наукового обгрунтування заходів з удосконалення та поліпшення функціонування систем захисту від наслідків надзвичайних ситуацій як важливої ланки національної безпеки.

Побудова теорії природно-техногенної безпеки повинна базуватись на понятійно-категоріальному апараті, який охоплює найсуттєвіші аспекти процесів, пов’язаних із забезпеченням безпеки складних систем.

Ключові слова: державне управління, надзвичайна ситуація, природнотехногенна безпека, техногенна безпека.

Sitsinsky Anatoliy Stanislavovich, Doctor of Sciences in Public Administration, Professor, Head of Research Department of Khmelnytsky University of Management and Law, Khmelnitsky city, st. Heroes of Maidan, 8, 29000, Ukraine, tel .: (038) -27-18000, e-mail: info@univer.km.ua

ORCID: 0000-0002-3299-5677

Slyusar Anatoliy Andriyovich Deputy Head of the Center for Civil Protection, Head of Civil Protection Development Department of the Ukrainian Research Institute for Civil Protection, Kiev, st. Rybalska, 8, 01011, Ukraine tel .: (044) -280-18-01, email: slusar_vrcz@undicz.dsns.gov.ua

ORCID: 0000-0002-3492-2092

\section{FEATURES OF PUBLIC MANAGEMENT BY TECHNOLOGICAL SAFETY}

Annotation. The article states that the current state of technogenic safety of Ukraine is of concern and requires constant attention from the state regarding the reduction and prevention of emergencies risks. The analysis of tendencies of increase of social and economic losses from natural and man-made emergency situations testifies to the necessity of forming an effective system of management of natural and man-made safety. The author focused attention on the fact that the formation of the system of management of natural and man-made safety should be based on two provisions, namely: the correct establishment of the ultimate goal and the search for appropriate means that provide an appropriate level of such security. The study of selected issues shows the need for effective management in emergencies and improving the effectiveness of the coordination of official government, departmental and nongovernmental activities through the development of a functional structure and the development of managerial skills, but also the transition to a new «management paradigm». 
It is noted that the management of natural and man-made safety is part of the systemic approach to decision-making, procedures and practical measures in solving tasks for the prevention or reduction of the danger of occurrence of industrial accidents and catastrophic natural processes for human life, diseases or injuries, damage to material values and the natural environment the environment, reducing the negative effects of catastrophic natural processes. At the same time, existing trends in the development of natural and man-made processes in Ukraine necessitate the further development and scientific substantiation of measures to improve and improve the functioning of emergency protection systems as an important part of national security.

The construction of the theory of natural and technological safety should be based on a conceptual categorical apparatus that covers the most important aspects of the processes involved in ensuring the safety of complex systems.

Key words: state administration, emergency situation, natural and man-made safety, technogenic safety.

Постановка проблеми. Сьогодні забезпечення техногенної безпеки в Україні розглядається як основна складова державної політики у сфері цивільного захисту та одна 3 найважливіших функцій органів державної влади і суб`єктів господарювання.

Одним із пріоритетних напрямів забезпечення безпечної життєдіяльності українського суспільства є посилення рівня превентивності державної політики у сфері цивільного захисту населення і територій від надзвичайних ситуацій. Сучасні науково-методологічні підходи та досвід розвинених країн свідчать, що ефективна модель такого захисту має грунтуватися на управлінні ризиками надзвичайних ситуацій техногенного характеру. Запровадження кількісних методів оцінки техногенних ризиків $є$ одним із стратегічних напрямів досягнення у державі прийнятного рівня безпеки для населення, навколишнього природного середовища та об ‘ктів економіки.

Проблема безпеки людини має глибокі історичні корені й безпосередньо пов'язана 3 появою людини розумної та необхідністю забезпечення життєдіяльності цього біологічного виду вже на етапі його становлення. Історичний досвід переконливо доводить, що потреба забезпечення безпеки належить до першочергових, основних мотивів діяльності людей і співтовариств. Потреба в безпеці належить до базисних і мотиваційних механізмів людської життедіяльності, як у будь-яких інших живих істот [1].

На початку XXI ст., незважаючи на великі досягнення науково-технічного прогресу, безпека залишається однією з центральних проблем цивілізаційного розвитку. Це обумовлено активізацією небезпечних природних і техногенних 
процесів, порушенням екологічного балансу i деградацією природного середовища, зростанням масштабів негативних наслідків техногенних катастроф.

Значне погіршення природно-техногенної ситуації спостерігається не тільки на локальному й регіональному, але й на глобальному рівнях. Тому пріоритетною постає проблема забезпечення безпеки життєдіяльності людини, суспільства й держави в умовах можливої реалізації природних і техногенних загроз.

Аналіз останніх досліджень $\boldsymbol{i}$ публікацій. Вітчизняними та зарубіжними науковцями розроблено теоретико-методологічні основи якісної та кількісної оцінки природно-техногенних ризиків, методи їх мінімізації. Проблемам управління ризиками надзвичайних ситуацій природно-антропогенного походження присвячені наукові доробки В. Акімова, Н. Асамбаєва, Б. Данилишина, В. Ковтуна, А. Степаненко, А. Качинського, Ю. Холмогорова, Б. Порфир'єва [1]. Проблемам державної політики у сфері техногенної безпеки та управління ризиками НС різного походження присвячено наукові доробки В. Гетьмана та Є. Буравльова, Н. Панкратова, Б. Порфирьєва, І. Шпильового. Можливості управління ризиками розглядаються Ю. Холмогоровим, роль і місце держави у процесі управління ризиками досліджено А. Качинським [2].

Підтримання стійкої динамічної рівноваги в будь-якій державі можливе лише за умов зменшення соціальних криз, катастроф i надзвичайних ситуацій та послаблення ступеня їхнього впливу на суспільство. Сучасний стан техногенної безпеки України викликає занепокоєння і потребує постійної уваги з боку держави щодо зменшення ризиків виникнення надзвичайних ситуацій (НС), питань захисту населення й територій від наслідків НС, забезпечення сталого розвитку країни. Це зумовлює необхідність проведення узгодженої політики безпеки між управлінськими, господарськими та суспільними інституціями нашої держави.

Формулювання цілей статmі. Мета статті полягає в системному аналізі понятійно-категоріального апарату теорії природно-техногенної безпеки та формуванні ефективної системи державного управління техногенною безпекою.

Виклад основного матеріалу дослідження. На сучасному етапі суспільного розвитку небезпека природних i техногенних, соціальних ризиків стала співрозмірна з воєнними загрозами. Аналіз тенденцій збільшення соціальноекономічних збитків від надзвичайних ситуацій (далі - НС) природного i техногенного спрямування засвідчує необхідність формування ефективної системи управління природно-техногенною безпекою (далі - СУ ПТБ), функціонування якої повинно бути спрямоване на розробку заходів забезпечення високого рівня природно-техногенної безпеки. 
Природний і техногенний ризик є факторами, які досить часто визначають якість життя населення країни. Рівень природного і техногенного ризику, якому піддається людина, залежить від трьох чинників: ймовірності виникнення $\mathrm{HC}$, їх масштабів і рівня захищеності, що забезпечується відповідними службами. Проблема зниження сукупного соціально-економічного ризику, особливості роботи в умовах НС спричиняють велику кількість завдань фундаментального та прикладного наукового спрямування. Насамперед, це завдання створення ефективної системи планування та оперативного управління комплексами заходів із попередження і ліквідації НС [3].

Тому вдосконалення систем управління, орієнтованих на прогноз i попередження НC, на захист населення і територій, має особливо велике значення.

Формування СУ ПТБ повинно базуватись на двох положення:

- правильного встановлення кінцевої мети;

- відшукання відповідних коштів, які забезпечують відповідний рівень ПТБ. При визначенні принципів формування СУПТБ треба враховувати, що управління - це процес, до якого належать:

- вироблення альтернативних керуючих впливів;

- прийняття рішення про вибір із них найефективніших;

- здійснень керуючих впливів 3 метою досягнення бажаних результатів функціонування керованого об’єкта.

При цьому ми будемо виходити 3 того, що керувати необхідно самим об’єктом, а не його ознаками і параметрами. При дослідженні проблем керування ПТБ керований об'єктами будемо трактувати як еколого-техногенну систему (далі - ЕТС), головними підсистемами якої є: екологічна, техногенна і соціальна.

Ми вважаємо, що еколого-техногенна система це певним чином організовані соціум, об’єкти економіки, техносфери, а також природно-територіальні екосистеми, які утворюють єдине структурно-функціональне ціле. Структурні підсистеми за своїми просторовими i iншими параметрами відповідають адміністративно-господарським територіальним утворенням та можуть бути різного рівня і масштабу - від національного до об'єктового.

Доцільність вибору ЕТС як об’єкта дослідження проблем безпеки природноантропогенних систем, на нашу думку, обумовлена такими чинниками:

а) ця система включає джерело небезпеки (екологічна, техногенна і соціальна підсистема) і потенційну жертву (об’єкт і суб'єкт небезпеки);

б) функціонування ЕТС адекватно відображає реальні природні і соціальноекономічні процеси; 
в) модель ЕТС дає змогу використовувати при аналізі небезпек загальносистемні принципи, що дає змогу певною мірою прогнозувати появу небезпечних ситуацій [1].

Першочерговими завданнями формування загальної теорії природнотехногенної безпеки є:

- формування базових понять і категорій (створення відповідного понятійнокатегорійного апарату);

- установлення структурно-функціональних зв’язків між базовими поняттями і категоріями;

- вибір підходів до формалізації процесів забезпечення безпеки складних систем і розробка на цьому підгрунті методів дослідження, які б забезпечили поглиблене дослідження та виявлення відповідних закономірностей;

- розробка методів формування механізмів забезпечення безпеки складних систем різної природи [4].

За допомогою аналізу структури і типу природних та техногенних загроз можна виокремити найбільш загальні принципи формування системи управління безпеки.

У загальному вигляді метою управління ризиками має бути забезпечення стійкого розвитку взагалі й техногенної безпеки зокрема. При цьому можна припустити, що кризи, катастрофи, НС та їхнє подолання - об’єктивний компонент процесу розвитку, який, поряд із негативними аспектами, містить у собі нові можливості розвитку суспільства.

У більш вузькому значенні метою управління ризиками у сфері техногенної безпеки є зменшення кількості та мінімізація соціально-економічних наслідків НС техногенного і природного характеру в Україні шляхом запровадження сучасних механізмів державного управління в цій сфері [2].

Ядром державної політики у сфері техногенної безпеки та, відповідно, управління техногенними ризиками мають стати економічні механізми. Їхнє призначення - утворити економічне підгрунтя функціонування цієї системи на всіх рівнях управління безпекою, починаючи від об'єктового i закінчуючи загальнодержавним.

В Україні необхідно вдосконалити ті, що існують, і ввести в дію інші економічні регулятори, які знайшли застосування у світовій практиці, а саме: податки, штрафи за шкідливі й небезпечні технології, санкції (відшкодування збитків, компенсація), страхування, фонди, пільги тощо. Механізми державного регулювання мають забезпечити оптимальний баланс економічних витрат і рівня техногенної безпеки в умовах обмежених ресурсів у державі. Метою державної політики є реалізація превентивних за своїм характером заходів, які мають бути 
спрямовані на зниження техногенних i природних ризиків для населення, територій, соціальних, техногенних і природних об’єктів.

На нашу думку. СУ ПТБ - це сукупність нормативних актів, організаційнотехнологічних заходів і ресурсів, які забезпечують нормальне функціонування ЕТС і мінімізацію наслідків реалізації небезпечних природно-техногенних процесів.

Найважливіше завдання управління СУ ПТБ - врахування інтересів особи, суспільства і держави в цій сфері. Інтереси особи в сфері ПТБ полягають у реалізації конституційних прав людини і громадянина на доступ до інформації, забезпечення фізичного, духовного та інтелектуального розвитку, а також доступ до інформації, що забезпечує особисту безпеку. Дотримання принципу балансу інтересів громадян, суспільства і держави передбачає законодавче закріплення пріоритету цих інтересів у різних сферах життєдіяльності суспільства, а також використання різних форм громадського контролю над діяльністю органів державної влади та органів державної влади регіональних суб’єктів щодо організації системи ПТБ [3].

Важливою метою функціонування СУ ПТБ $є$ попередження природнотехногенних катастроф і аварій, своєчасне прийняття заходів щодо локалізації i ліквідації наслідків НС природного і техногенного характеру, раціональне використання ресурсів системи для забезпечення ПТБ.

Загалом, функції держави стосовно управління ПТБ полягають у наступному:

- здійснення об’єктивного і всебічного аналізу та прогнозування природнотехногенних загроз;

- організація робіт органів влади щодо реалізації комплексу заходів, спрямованих на запобігання і нейтралізацію загроз ПТБ;

- підтримка діяльності громадських об’єднань, спрямована на об’єктивне інформування населення щодо проблем ПТБ, надання фізичним і юридичним особам доступу до інформаційних ресурсів, глобальних інформаційних мереж;

- організація розробки державної програми забезпечення ПТБ, яка об’єднує зусилля державних і недержавних організацій [1].

Суттєва специфіка СУ ПТБ полягає у тому, що вона може функціонувати в таких режимах:

- повсякденної діяльності;

- підвищеної готовності;

- надзвичайної ситуації.

Специфікою СУ ПТБ є те, що на відміну від ринкової економіки, командноадміністративні методи керування, дотримання принципу особистої відповідальності на об’єктах, що представляють небезпеку для життя і здоров’я 
людей, $є$ необхідним і ефективним елементом управління в умовах використання небезпечних технологій та в умовах дефіциту часу.

СУ ПТБ вимагає розробки науково обгрунтованої стратегії, яка повинна включати такі основні моменти:

- розробку єдиного підходу до класифікації ризиків;

- організацію відділів із управління ризиком на підприємствах;

- створення і впровадження методики реєстрації збитків у матеріальному та економічному виразі;

- створення і впровадження методики прогнозування аварійних ситуацій, оцінки можливих наслідків;

- формування глобальної бази даних щодо збитків у межах окремих об’єктів та цілої галузі;

- розробку методики оцінки порівняння ефективності різних заходів із управління ПТБ та рекомендацій щодо їх використання в конкретних випадках;

- активне використання страхування і самострахування.

Функціонування СУ ПТБ в умовах НС характеризується низкою особливостей, а саме: небезпека, дефіцит часу, особливості виконуваної роботи і iї організації, відносна ізоляція, відповідальність.

Серйозною проблемою організації ефективного управління в умовах НС $\epsilon$ відсутність координації діяльності офіційних урядових, відомчих і неурядових органів. Часто виникає плутанина при вирішенні питання, чим має займатися певна установа. Це призводить до дублювання роботи в одних областях i бездіяльності в інших. Проте традиційні підходи до управління в умовах $\mathrm{HC}$, як показує досвід їх використання, призводять до незадовільних результатів.

Вирішувати проблему управління в умовах НС необхідно не тільки шляхом розбудови функціональної структури та підвищення кваліфікації управлінських кадрів, але і переходу до нової “управлінської парадигми”, що означає систему поглядів, що базуються на основних положеннях ситуаційного управління. Ефективність СУ ПТБ пов'язують із тим, наскільки вдало вона реагує на зміну зовнішнього оточення, наскільки вона стійка до несподіваних змін зовнішнього середовища і наскільки ефективно використовує свої потенційні можливості.

При складній i мінливій структурі оточуючого середовища система управління насамперед повинна бути гнучкою і адаптивної. Вона повинна бути пристосована до визначення нових проблем та вироблення нових рішень більшою мірою, ніж до контролю вже прийнятих рішень та їх реалізації. У них повинна бути забезпечена можливість максимальної концентрації ресурсів, об'єднання інформаційних, організаційних та інших типів ресурсів для ліквідації наслідків НС у найкоротші терміни. 
Для СУ ПТБ характерним $є$ поєднання двох, в звичайних умовах взаємовиключних), принципів: єдиноначальність (єдність повноважень і відповідальності) та розподіл повноважень і відповідальності. 3 одного боку, керівник несе персональну відповідальність за стан справ, з іншого - у роботі центру, в якому вирішуються питання взаємодії і координації між керівниками різних рівнів та зон розвитку $\mathrm{HC}$, реалізується принцип розподіленої відповідальності. У центрі створюються умови для необхідних погоджень і консультацій для усунення неминучих конфліктів та розбіжностей. Це забезпечує мінімальне втручання перших осіб в оперативну діяльність керівників нижчих рівнів [3].

Організаційна структура СУ ПТБ в умовах НС повинна бути 3 локальною автономією і глобальної координацією. Ї̈̈ різні елементи беруть участь у встановленні цілей і завдань та спільними зусиллями домагаються їх реалізації.

Висновки. Отже, досягнення нових якісних та кількісних змін у техногенній безпеці можливе лише за умов комплексного дослідження питань державного управління та порівняння особливостей європейських підходів у сфері техногенної безпеки як щодо структур управління окремими об'єктами, так і стосовно загальної системи управління всією безпекою держави. Це є правилом безпечного формування продуктивних сил України, створення екологічно- та техногенно-безпечних умов життєдіяльності в контексті гармонійного розвитку, що зумовлюють необхідність грунтовних наукових досліджень щодо розвитку всієї сфери національної безпеки та ії складової - промислової безпеки згідно із сучасною філософією безпеки.

Отже, існуючі тенденції в розвитку природно-техногенних процесів в Україні обумовлюють необхідність подальшої розробки та наукового обгрунтування заходів з удосконалення та поліпшення функціонування систем захисту від наслідків надзвичайних ситуацій як важливої ланки національної безпеки.

В той же час НС природно-техногенного спрямування стають постійними і все більш важливою частиною соціального розвитку. Для України винятково важливим $є$ прийняття концепції управління ПТБ, яка повинна відображати вибір суспільства і визначати головні напрямки досягнення високого рівня природнотехногенної безпеки.

\section{Jimepamypa:}

1. Соха Ю. І. Формування понятійно-категоріального апарату теорії природнотехногенної безпеки: державно-управлінський аспект. Державне управління та місиеве самоврядування : журнал. 2014. Вип. 1(20). С. 42-51. 
2. Швидич О. І. Формування та реалізація політики у сфері управління техногенною безпекою України. Теорія та практика державного управління : журнал. 2008. Вип. 3. С. 374379.

3. Серант А. Й., Соха Ю. І. Особливості і принципи формування системи державного управління природно-техногенною безпекою. Ефективність державного управління : журнал. 2012. Вип. 32. С. 457-465. URL : http://nbuv.gov.ua/UJRN/efdu_2012_32_57.

4. Іванюта П. В. Державне регулювання еколого-техногенною безпекою України. Державне управління: удосконалення та розвиток : журнал. 2010. № 8. URL : http://nbuv.gov.ua/UJRN/Duur_2010_8_5.

\section{References:}

1. Sokha, Yu. I. (2014). Formuvannia poniatiino-katehorialnoho aparatu teorii pryrodnotekhnohennoi bezpeky: derzhavno-upravlinskyi aspekt [Formation of the conceptual-categorical apparatus of the theory of natural and technological safety: the state-management aspect]. Derzhavne upravlinnia ta mistseve samovriaduvannia - Public Administration and Local Government, 1(20), 4251 [in Ukrainian].

2. Shvydych, O. I. (2008). Formuvannia ta realizatsiia polityky u sferi upravlinnia tekhnohennoiu bezpekoiu Ukrainy [Formation and implementation of policy in the field of man-made safety management in Ukraine]. Teoriia ta praktyka derzhavnoho upravlinnia - Theory and Practice of Public Administration, 3, 374-379 [in Ukrainian].

3. Serant, A. Y., Sokha, Yu. I. (2012). Osoblyvosti i pryntsypy formuvannia systemy derzhavnoho upravlinnia pryrodno-tekhnohennoiu bezpekoiu [Peculiarities and Principles of the Formation of the State Administration of Natural and Man-made Safety]. Efektyvnist derzhavnoho upravlinnia - Public Administration Efficiency, 32, 457-465. Retrieved from http://nbuv.gov.ua/UJRN/efdu_2012_32_57 [in Ukrainian].

4. Ivaniuta, P. V. (2010). Derzhavne rehuliuvannia ekoloho-tekhnohennoiu bezpekoiu Ukrainy [State regulation of ecological and technogenic safety of Ukraine]. Derzhavne upravlinnia: udoskonalennia ta rozvytok - Public Administration: Improvement and Development, 8. Retrieved from http://nbuv.gov.ua/UJRN/Duur_2010_8_5 [in Ukrainian]. 